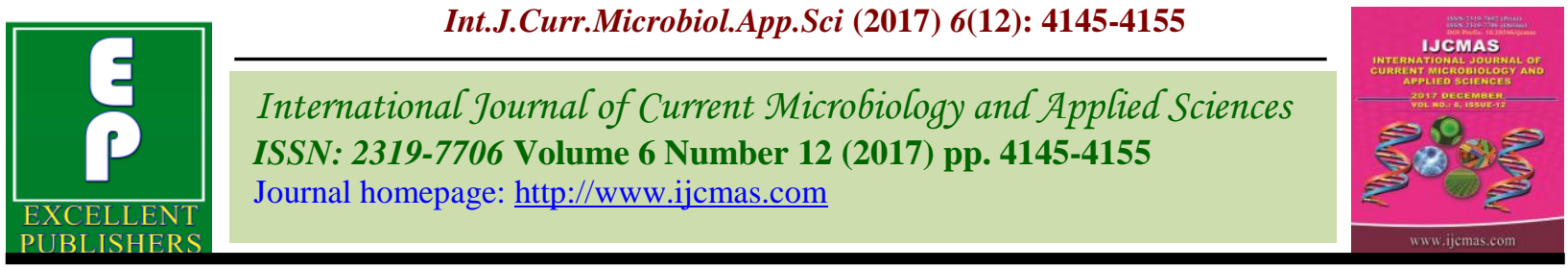

Review Article

https://doi.org/10.20546/ijcmas.2017.612.476

\title{
Impact of Boron Nutrition in Fruit Crops
}

\author{
Gowhar A. Dar* \\ Division of Fruit Science, Sher-i-Kashmir University of Agricultural Sciences and Technology \\ of Kashmir, Shalimar Campus (191 121) J\&K, India \\ *Corresponding author
}

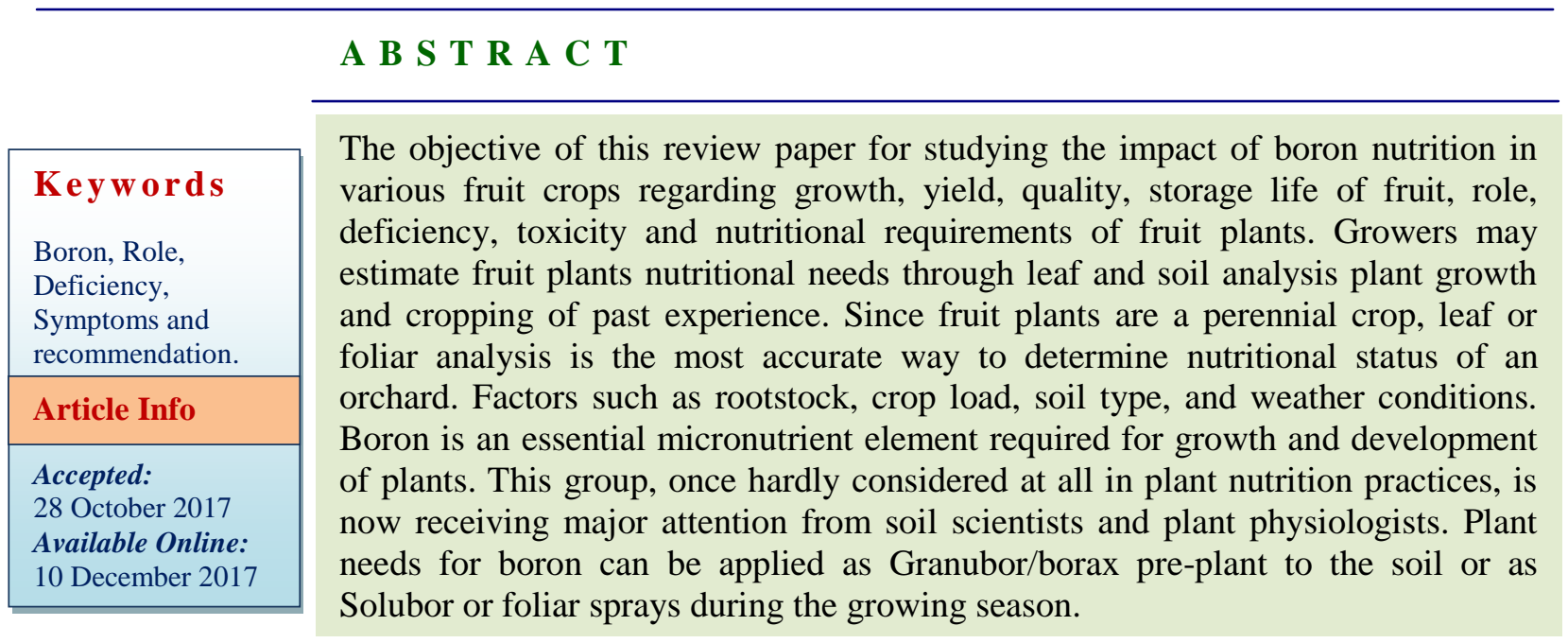

\section{Introduction}

World-wide, boron deficiency is more extensive than deficiency of any other plant micronutrient (Gupta, 1979). It is particularly prevalent in light textured soils, where watersoluble boron readily leaches down the soil profile and becomes unavailable for plants. Adequate boron nutrition is critical not only for high yields but also for high quality of crops. Boron deficiency causes many anatomical, physiological, and biochemical changes, most of which represent secondary effects. Because of the rapidity and the wide variety of symptoms that follow boron deprivation, determining the primary function of boron in plants has been one of the greatest challenges in plant nutrition. In recent years, research has progressed to the point where it is possible to demonstrate boron involvement in three main aspects of plant physiology. Thus, this review article features an in-depth look at a structural role for boron in cell walls, a role for boron in membrane function, and boron involvement in metabolic activities. This group once hardly considered at all in plant nutrition practices is now receiving major attention from soil scientists and plant physiologists. Boron is generally considered phloem immobile in some fruit trees, foliar application of boron in the fall temporarily increased boron concentration of leaves, but during late fall and winter boron moved to the bark. In spring, the boron 
moved from the bark into flowers and resulted in increased fruit set. Boron is an essential element and plays an important role in the ribonucleic acid metabolism, synthesis and stability of nuclear membranes and in the transport of assimilates, mainly sugars (Marschner, 1995).

\section{Symptoms of boron deficiency in soil and plants}

Boron deficiency is particularly prevalent in light textured soils, where water-soluble boron readily leaches down the soil profile and becomes unavailable for plants. Boron deficiency may also occur on a soil with adequate boron level if its uptake is impended by over liming, dry or wet soil conditions, and a low level of soil oxygen (Goldberg, 1997; Wojcik, 2003). Adequate boron nutrition is critical not only for high yields but also for high quality of crops. Boron deficiency causes many anatomical, physiological, and biochemical changes, most of which represent secondary effects (Blevins and Lukaszewski, 1998). Boron is an essential nutrient required for higher plants (Marschner, 1995). Boron has been found to play a key role in reproductive processes affecting anther development, pollen germination, and pollen tube growth (Loomis and Durst, 1992; Robbertse et al., 1990). For this reason, in boron-sensitive crops abortion of flower initials and poor set of fruit or seeds are observed under conditions of boron deficiency (Goldbach, 1997; Mozafar, 1993). The primary effect of boron deficiency appears to be the disruption of the normal functioning of the apical meristems with changes in membrane structure, cell wall synthesis, metabolisms of auxin, carbohydrate, ascorbate, RNA, lignifications, phenol accumulation and sucrose transport being secondary effects (Parr and Loughman, 1983; Blevins and Lukaszewski, 1998; Brown et al., 2002).
Apple (Malus domestica Borkh.) trees have been known to have high requirements of boron (Shorrocks, 1997). Poor fruit set and in turn reduced yielding are first visual signs of boron deficiency since this nutrient plays a key role in the reproductive growth (Robbertse et al., 1990; Loomis and Durst, 1992). Apples of boron deficient trees are small, deformed, corked, and sensitive to cracking and russeting and have yellow skin with a poor red colour (Peryea, 1994). Under boron deficiency conditions, apple fruits may also have low concentrations of soluble solids and acids (Shear and Faust, 1980). Besides Pomaceous fruits, stone fruits are also affected by boron deficiency severely, like boron-deficient cherry shoots grow for some time and then tips die. Leaves are distorted in shape, with irregular serration, and may cup or roll downward. Under conditions of B deficiency, splitting of the bark frequently occurs. Some buds of B-deficient plants may fail to open in the spring, whereas others shrivel and die. Cracking, shriveling, deformation, internal and external browning, and corking around pit and in flesh are signs of cherry fruit B deficiency (Wojcik and Wojcik, 2006). Nut crops of temperate areas also show the similar response to low boron soils (Table 1).

\section{Forms and sources of boron in soils}

\section{Total boron}

The total boron content of most agricultural soils ranges from 1 to $467 \mathrm{mg} \mathrm{kg}^{-1}$, with an average content of 9 to $85 \mathrm{mg} \mathrm{kg}^{-1}$. Total boron in major soil orders, Inceptisol and Alfisol, in India ranged from 8 to $18 \mathrm{mg} \mathrm{kg}^{-1}$. Such wide variations among soils in the total boron content are mainly ascribed to the parent rock types and soil types falling under divergent geographical and climatic zones. Boron is generally high in soils derived from marine sediments. 


\section{Available boron}

Available boron, measured by various extraction methods, in agricultural soils varies from 0.5 to $5 \mathrm{mg} \mathrm{kg}^{-1}$. Most of the available boron in soil is believed to be derived from sediments and plant material. Few studies have been conducted that attempt to identify solid-phase controls on boron solubility in soils. Most of the common boron minerals are much too soluble for such purposes (Lindsay, 1991).

\section{Soil solution boron}

In soil solution, boron mainly exists as undissociated acid $\mathrm{H}_{3} \mathrm{BO}_{3}$. Boric acid [also written as $\mathrm{B}(\mathrm{OH})_{3}$ ] and $\mathrm{H}_{2} \mathrm{BO}_{3}$ are the most common geologic forms of boron, with boric acid being the predominant form in soils as reviewed by Evans and Sparks (1983). They further reported that boric acid is the major form of boron in soils with $\mathrm{H}_{2} \mathrm{BO}_{3}$ being predominant only above $\mathrm{pH}$ 9.2. In their review, they stated that boron occurs in aqueous solution as boric acid $\mathrm{B}(\mathrm{OH})_{3}$, which is a weak monobasic acid that acts as an electron acceptor or as a Lewis acid.

\section{Tourmaline}

In most of the well-drained soils formed from acid rocks and metamorphic sediments, tourmaline is the most common boroncontaining mineral identified (Whetstone et al., 1942). The name tourmaline represents a group of minerals that are compositionally complex borosilicate containing approximately $3 \%$ boron. The tourmaline structure has rhombohedra symmetry and consists of linked sheets of island units. The boron atoms are found within $\mathrm{BO}_{3}$ triangles, forming strong covalent $\mathrm{B}-\mathrm{O}$ bonds (Tsang and Ghose, 1973). Tourmalines are highly resistant to weathering and virtually insoluble. Additions of finely ground tourmaline to soil failed to provide sufficient boron to alleviate boron deficiency of crop plants (Fleming, 1980).

\section{Role of boron in physiology of plants}

\section{Boron phloem mobility and transport molecules}

In vascular plants, boron moves from the roots with the transpiration stream and accumulates in growing points of leaves and stems. It has been suggested that these local concentrations in apical tissues led to the evolutionary development of dependency on boron for some aspects of metabolism in plant meristems. Once in the leaves, boron retranslocation is restricted and it becomes fixed in the apoplast. Based on this pattern, boron is generally considered phloem immobile. However, tracer studies with stable isotope 10B demonstrated that in some fruit trees, foliar application of boron in the fall temporarily increased boron concentration of leaves, but during late fall and winter boron moved to the bark. In the spring, the boron moved from the bark into flowers and resulted in increased fruit set. Subsequently ( $\mathrm{Hu}$ and Brown, 1994) evaluated boron mobility in some species within the genera of Pyrus, Malus, and Prunus and connected their phloem boron transport with the key fact that these species transported carbon as polyols. Since the beginning of the twentieth century, chemists have used polyols, such as glycerol or mannitol, to enhance the acidity of borate solutions. The basis for these reactions is the ability of borate to form cyclic diesters with some diols and polyols. (Brown and Associates., 1997) isolated and characterized soluble sorbitol-boron-sorbitol complexes from the floral nectar of peach and mannitolboron-mannitol complexes from phloem sap of celery. This was the first isolation and identification of boron transport molecules in plants. Brown's group also obtained evidence 
for phloem boron movement in species transporting dulcitol (Hu H., et al., 1997). These results explain much of the confusion about boron phloem mobility in plants. We can now conclude that phloem movement of boron depends on the sugar or polyol transport molecules used by the particular plant. Adequate levels of this element enhance pollen germination and pollen tube growth in almond trees (Nyomora et al., 2000) improving fruit set and seed growth. Foliar application of B just before leaf fall can greatly increase B levels in flower buds and increase fruit set in sour cherry (Thompson, 1996). Boron applied to trees in the autumn moves from the leaves into the adjacent buds, where elevated levels are maintained and expressed in flowers at a thesis. The B supplied to the flowers is largely derived from reserves in the wood which are mobilized during floral development.

\section{Cell wall structure}

The primary cell wall of higher plants is an important factor determining cell size and shape during plant development. The mechanical properties of growing cell walls can be modified by cross links between their major components, cellulosic polymers, and matrix polymers such as hemi cellulosic and pectic polysaccharides (Carpita, 1987). Over the years, researchers have observed a close relationship between the primary cell walls and boron nutrition up to $90 \%$ of the cellular boron has been localized in the cell wall fraction. The first symptoms of boron deprivation include abnormalities in cell wall and middle lamella organization $(\mathrm{Hu} \mathrm{H}$ Brown, 1994). Recently formation of borate esters with hydroxyl groups of cell wall carbohydrates and/or glycoprotein's has been proposed as a mechanism for cross linking cell wall polymers. Borate bridging could explain many of the characteristics of borondeficient and boron-toxic plants. This type of bonding could account for brittle leaves of boron-deficient plants, while plants grown with supraoptimal levels of boron produce leaves that are plastic or elastic in their response to bending (Gauch et al., 1954). In addition, the slipping and sliding properties of "slime" (Casassa et al., 1986) permitted by the H-bonding of hydroxyl groups on borate molecules and the hydroxyl groups of the polyvinyl alcohol, could explain the properties of primary cell walls at early stages of development (Carpita, 1987). It was an early observation that plant boron content was closely correlated with pectin (Gauch et al., 1954). In 1961, Ginsburg showed that a strong chelator, EDTA, mixed with a weak chelator (e.g. IAA), was effective in causing cell separation by removing the pectin/protein matrix, but borate buffer kept the matrix intact longer than any other buffer. Clarkson and Hanson (1980) proposed that by forming cross links in pectin, boron protects $\mathrm{Ca}$ in the cell wall.

\section{Membranes and membrane-associated reactions}

The evidence provided by cell wall studies explains many problems caused by boron deficiency. However, there are some aspects of plant boron nutrition that go beyond cell wall structure. These include rapid changes in membrane function induced by addition of boron to boron-deficient tissues. Boron was first localized in maize root membranes by (Pollard et al., 1977) and was later found in membrane fractions from protoplasts of mung bean by Tanada (1983). Although the quantities of boron in membranes were not large, especially compared with those in cell wall fractions, they were significant for ion uptake. Lawrence et al., (1995) showed lower ATPase activity in plasma lemma-enriched vesicles from boron-deficient chickpea roots than in vesicles from control roots, and Obermeyer et al., (1996) reported boron 
stimulation of the plasma lemma ATPase from ungerminated pollen grains of lily. Barr and Crane $(1993 ; 1994)$ showed that addition of exogenous boric acid (with or without 2, 4D) to low boron cells caused an instantaneous stimulation of the plasma membrane NADH oxidase. This was the fastest boron response reported. By stimulating NADH oxidase, boron could be involved in keeping ascorbate reduced at the cell wall/membrane interface. It is noteworthy that both NADH oxidase activity and ascorbate have been linked with plant growth processes (Gonzales et al., 1994; Morre et al., 1986). In summary, boron treatment of low-boron plants stimulates ATPase activity, NADH oxidase activity, and ion transport (Barr et al., 1993). Though these changes are associated with membrane function, several researchers have speculated that boron may be affecting physical properties of membrane proteins. In addition, Shkolnik (1984) observed that several enzymes, normally bound to membranes or walls in a latent form, become active when released under boron deficient conditions. These enzymes include ribonuclease, glucose6-phosphate dehydrogenase, phenylalanine ammonia lyase, $\beta$-glucosidase and polyphenoloxidase. Release of these enzymes under boron-insufficient conditions could severely alter plant metabolism, deplete RNA, and increase phenolic synthesis. Many of the phenolics are potent growth inhibitors the same phenolics also inhibit ion uptake and thus retard membrane function (Glass and Dunlop, 1974).

Reproduction, pollen tube growth, and pollen germination

Based on the latest research, cell wall composition may be of primary importance in determining the quantity of boron required for growth. However, it has been observed that in most plant species the boron requirement for reproductive growth is much higher than for vegetative growth (Loomis and Durst, 1992). The physiological basis for the high boron demand for plant reproduction is not fully understood. Boron requirement for reproductive growth in plants has long been recognized. Gauch and Dugger (1954) proposed that boric acid was bound to hydroxyl-rich organic molecules, like sugars, and was involved in pollen tube wall formation. Pollen grains of most species are naturally low in boron, but in the styles, stigma, and ovaries, boron concentrations are generally high. Visser (1955) showed that a continuous and ample supply of boron was required for pollen tube growth, and speculated that the boron was complexing with cellular materials during the tube elongation process. Along this line, Johri and Vasil (1961) demonstrated that boron was more critical for pollen tube elongation than for pollen germination. Rapid growth of pollen tube depends on constant fusion of vesicles forming the plasma lemma, and continuous secretion of cell wall material. Whatever the mechanism, the role of boron in reproductive growth is particularly striking. The uniformly high boron requirement for reproductive growth across the plant kingdom is intriguing and indicates similarities between reproductive structures, so unlike cell walls, perhaps the composition of the pollen tube wall is similar across plant species.

\section{Sites of boron action in plant metabolism}

Primary cell wall structure and membrane function are now closely linked to boron nutrition. In contrast, boron role in plant metabolism is still a subject of considerable debate. Focusing on the diversity of early responses to boron deficiency, Lovatt and Dugger (1984) postulated that boron can be involved in a number of metabolic pathways and can act in regulation of metabolic processes similarly to plant hormones. 
However, due to a lack of suitable information, boron function in metabolic events has never been properly evaluated. There is substantial evidence supporting the association of boron with ascorbate metabolism. One way boron could increase ascorbate concentration is through its effect on plasma membrane electron transport reactions. Barr and associates (1993) showed that boron instantaneously stimulated the auxin-sensitive plasma lemma NADH oxidase. This enzyme, also called ascorbate free radical oxidoreductase (Morre et al., 1986), catalyzes the transfer of electrons to ascorbate free radical. Inhibition of this process in the absence of boron could result in deprivation of reduced ascorbate. Another site of boron action that is not connected with a structural role in cell walls or membranes is auxin metabolism. Boron interaction with auxin has long been postulated, and although the issue remains controversial, it may be central to our understanding of the role of boron in plants. In 1977, Bohnsack and Albert demonstrated a 20-fold increase in IAA oxidation rate in root apices $24 \mathrm{~h}$ after boron was withheld from the nutrient medium. The authors attributed the increase to stimulation of the activity by high levels of IAA accumulated in boron-deficient tissues.

\section{Role of boron in temperate fruits}

It is clear that Wojcik et al., (2008) has observed that foliar boron spray has no effect on boron status in leaf and fruit tissues, indicating that absorption rate of foliar applied boron and/or re-translocation of boron in plant as limited. Besides, phloem boron mobility in apple is good (Brown and $\mathrm{Hu}$, 1996), it seems that a lack of effect of foliar boron sprays on boron level in leaf was related to restricted boron absorption rate by spur leaves. This is possible because spur leaf area of apple tree at beginning of the growing season is small (Wojcik et al., 2008). Hence early season boron spray has little or no effect on summer leaf boron concentration of apple trees. These results were in agreement with the findings of Bramlage and Thompson (1962) and Khalil and Thompson (1965). In contrary to these results Peryea et al., (2003) showed increased mid-season leaf boron status as a result of pre-bloom boron sprays. The opposite results of the above two studies on the effect of foliar boron sprays on midsummer leaf boron status could be due to different soil properties affecting behavior of boron in the soil and consequently its uptake by plants (Wojcik et al., 2008).

It shows increase in net photosynthetic rate which may be attributed to increase in chlorophyll content of leaves. Moreover, soil boron application increased the activity of catalase and glutathione reductace, which act as antioxidants thus saving the electron transport mechanism of plant from getting oxidized by free radicles like superoxide radicles, singlet oxygen radicles etc. (Wojcik et al., 2008).

Thurzo (2010) has observed the increase in the content of chlorophylls and carotenoids by foliar application of boron in sweet cherry at full bloom. Due to the above effect, the increase in the rate of photosynthesis is inevitable.

\section{Effect of boron respiration in temperate fruits}

There is generally less literature concerning the influence of boron on fruit respiration. Besong and Lawanson (1991) confirmed that the activity of respiratory enzymes was intensified under boron deficiency, but lowered by boron application. The ethylene production in B-treated fruit was reduced, most effectively after $\mathrm{B}+\mathrm{Ca}$ application. The functions of boron and Calcium on the structure of cell walls and cell membranes are well known (Marschner, 1997). 
Table.1 Boron deficiency symptoms in various fruit crops

\begin{tabular}{|l|l|}
\hline Crop & \multicolumn{1}{|c|}{ Visible Symptoms } \\
\hline Almond & Flowers fall and nuts abort or gummy. \\
\hline Apple & Pitting, skin discolored, cracking and corking. \\
\hline Apricot & Pitting, skin discolored, cracking and corking. \\
\hline Prunes & $\begin{array}{l}\text { Excessive multiple branching in tree tops, Bushy branch, } \\
\text { marked reduction in fruit set, brown sunken areas in fruit. }\end{array}$ \\
\hline Grape & "Hen \& chicken" symptom, dead main shoots. \\
\hline Pear & Blossom blast, pitting, internal corking and bark cankers. \\
\hline Peanut & Dark, hollow area in center of nut, called "hollow heart" \\
\hline Pistachio & Fruit set decreases, and blanks and non-split nuts increase. \\
\hline Strawberry & Pale chlorotic skin of fruit, cracking and die back. \\
\hline Walnut & Dieback from shoot tips, leaf fall. \\
\hline
\end{tabular}

(Source Spectrum Analytic Inc 1087 Jamison Rd NW Washington Court House, OH 43160 (800) 321-1562)

Table.2 Effect of boron on fruit set, yield and quality of apple.

(Adopted from Wojcik et al., 2008)

\begin{tabular}{|c|c|c|c|c|c|c|c|}
\hline \multirow{2}{*}{ Treatment } & \multicolumn{3}{|c|}{ Fruit Set (\%) DAF } & \multirow{2}{*}{$\begin{array}{c}\text { Yield } \\
(\mathrm{Kg} / \text { tree })\end{array}$} & \multirow{2}{*}{$\begin{array}{l}\text { Mean Fruit } \\
\text { Weight }(\mathrm{g})\end{array}$} & \multirow{2}{*}{$\begin{array}{l}\text { TSS } \\
(\%)\end{array}$} & \multirow{2}{*}{$\begin{array}{c}\text { Acidity } \\
(\%)\end{array}$} \\
\hline & 14 & 28 & 42 & & & & \\
\hline $\begin{array}{l}\text { Soil B } \\
\text { Application }\end{array}$ & 36.2 & 15.3 & 7.2 & 4.3 & 226 & 13.6 & 0.72 \\
\hline $\begin{array}{l}\text { Foliar B } \\
\text { Application }\end{array}$ & 40.2 & 25.3 & 15.2 & 6.8 & 191 & 12.5 & 0.65 \\
\hline Control & 39.4 & 11.4 & 6.9 & 3.1 & 188 & 12.4 & 0.63 \\
\hline
\end{tabular}

$\mathrm{Ca}$ and/or $\mathrm{B}$ can maintain cell compartmentation so that the ethylene could be less formed during the ripening of Btreated fruit. Another possibility might be that the formation of methionine, a precursor of ethylene, is affected by boron.

Xuan et al., (2003) observed that boron treated fruit showed continuously lower $\mathrm{O}_{2}$ uptake and $\mathrm{CO}_{2}$ emission under controlled atmospheric conditions as well as under cool storage conditions. At the same time, it was noticed that $\mathrm{O}_{2}$ uptake under controlled atmospheric conditions in B-treated and Buntreated fruit was clearly decreased more than the corresponding $\mathrm{CO}_{2}$ emission. At harvest, no ethylene was found in all treatments. After one month of controlled atmospheric storage, the formation of ethylene started and increased till the end of 5-months storage period. At the same time, the $\mathrm{B}$ and $\mathrm{B}+\mathrm{Ca}$ treatments produced less ethylene than the control fruit. The $\mathrm{B}+\mathrm{Ca}$ treatment always had the lowest rate of ethylene formation.

\section{Effect of boron application on fruit set, yield and fruit quality of temperate fruits}

Boron is important in pollen germination and pollen tube growth which is likely to increase fruit set (Wojcik et al., 2008). Therefore, B 
fertilization may increase yield, particularly when plants are grown on sandy soil with a low content of available B as shown by Wojcik et al., (2008) and Nyomora and Brown (1997). Although the mechanism of B translocation within plants has not been well understood the effect of $\mathrm{B}$ fertilization of apple trees on fruit quality as altered by several biological and environmental factors such as cultivar, orchard location, rainfall, air temperature has been well known for many years (Wilcox and Woodbridge, 1942; Haller and Batjer, 1946).

Wojcik et al., (2008) observed that pre bloom foliar application of boron to apple trees (Table 2) increases fruit set as well as yield moreover soil application of boron also increases yield but to a lesser extent. Further the author explains the increase in yield through soil application of boron to be due to increase in fruit size and through increase in fruit number in case of foliar spray. Besides increasing fruit set and yield Wojcik et al., (2008) reported an increase in total soluble solids as well as total acidity due to soil boron application. This can be because of transportation of higher amount of assimilates into fruit tissues.

It may be concluded that application of Boron during flowering increased the growth of the pollen tube and in the development of the flowering and fruiting stages. Boron foliar sprays to Boron deficient fruit trees under dry conditions delay bloom and increase fruit set and final fruit number per tree. Also, these sprays result in improved yields, mainly when both fall and spring Boron foliar sprays are applied. Soil and foliar application of Boron increased yield, however Boron sprays were more efficient than soil fertilization. Foliar Boron sprays increased the Boron content of apple, pear, plum and sour cherry leaves. It should be underlined that fall foliar Boron sprays increased Boron status in flowers and leaves, indicating that leaf-absorbed Boron moved out of leaves into adjacent twigs and supplied developing flowers and leaves in the following growing season.

\section{References}

Barr, R., Bottger, M. and Crane, F. L. 1993. The effect of boron on plasma membrane electron transport and associated proton secretion by cultured carrot cells. Biochemistry and Molecular Biological Institute, 31: 3139.

Besong, B. E. and Lawanson, A. O. 1991. Boron stress and mitochondrial quinone accumulation in Zea mays seedlings. Journal of Plant Physiology, 138: 8084.

Blevins, D. G. and Lukaszweski, K. M. 1998. Boron in plant structure and function. Annual Review of Plant Physiology and Plant Molecular Biology, 49: 481-500.

Bohnsack, C. W. and Albert, L.S. 1977. Early effects of boron deficiency on indole acetic acid oxidase levels of squash root tips. Plant Physiology, 59: 1047-50.

Brown, P. H., Belleloui, N., Wimmer, M. A., Bassil, E. S., Ruiz, J., Hu, H. and Pfefer, H., Dannel, F. and Romheld, V. 2002. Boron in plant biology. Plant Bilology, 4: 205-223.

Brown, P.H. and Hu, H. 1996. Phloem mobility of boron is species dependent: Evidence for phloem mobility in sorbitol-rich species. Ann. Bot. 77:497505.

Carpita NC. 1987. The biochemistry of the growing plant cell wall. In physiology of cell wall expansion during plant growth, ed. DJ Cosgrove, DP Keievel, pp. 28-45. Rockville, MD: Am. Soc. Plant Physiol.

Casassa EZ, Sarquis AM, VM, Van Dyke CH. 1986. The gelation of polyvinyl alchol with borax. A novel class participation 
experiment of a "slime", J. Chem. Educ. 63:57-60.

Clarkson DT, Hanson JB. 1980. The mineral nutrition of higher plants. Ann. Rev. Plant Physiol. Plant Mol. Biol. 31: 23998

Dale G. Belvins and Krystyna M. Lukaszewski. 1998. Boron in plant Structure and Function. Annu. Rev. Plant physiol. Plant Mol. Biol. 1998. 49: 481-500.

Evans, C. M. and Sparks, D. L. The chemistry and mineralogy of boron in pure and in mixed systems: a review. Communications of Soil Science. Plant Analysis. 14: 827-846, 1983.

Fleming, G. A. Essential micronutrients I: Boron and molybdenum. In: B. E. Davies, ed. Applied Soil Trace Elements. New York: Wiley, 1980, pp. 155-197.

Gauch HG, Dugger WM Jr. 1954. The physiological action of boron in higher plants: A review and interpretation. College Park: Univ. Md., Agric. Exp. Stn.

Ginsgurg BZ. 1961. Evidence for a protein gel structure crosslinked by metal cations in the intercellular cement of plant tissue. J. Exp. Bot. 12:85-107

Glass A D M, Dunlop J. 1974. Influence of phenolic acids on ion uptake. IV. Depolarization of membrane potentials. Plant Phyiol. 54: 855- 58.

Goldbach, H. E. 1997.A critical review on current hypothesis concerning the role of boron in higher plants: suggestions for further research and methodology requirements. Journal of Trace Microprobe Technology. 15: 51-91.

Gonzales-Reyes, J. A., Alcain, F. J., Caler, J. A., Serrano, A., Cordoba. F. and Navas, P. 1994. Relationship between apoplastic ascorbate regeneration and the stimulation of root growth in Allium cepa L. Plant Science 100: 23-29.
Gupta, U C. 1979. Boron nutrition of crops. Adv. Agron., 31: 273 - 307.

Haller, M. H. and Batjer, L. P. 1946. Storage quality of apples in relation to soil application of boron. Journal of Agriculture Research 73: 243-253.

HU H, Penn SG, Lebrilla CB, Brown PH. 1997. Isolation and characterization of soluble boron complexes in higher plants. Plant physiol. 113:649-55

$\mathrm{Hu}, \mathrm{H}$. and Brown, P. H. 1994. Localization of boron in cell walls of squash and tobacco and its association with pectin: evidence for a structural role of boron in the cell wall. Plant Physiology. 105: 681-689.

Johri, B. M.and Vasil, I. K. 1961. Physiology of pollen. Botanical Review. 27: 32581.

Khalil, T. S. and Thompson, A. H. 1965. Seasonal content of boron of Stayman apple trees as influenced by boron sprays. Proc. American Society of Horticultural Science. 77: 35-42.

Lawrence, K., Bhalla, P. and Misra, P. C. 1995. Changes in (NADP) H-dependent redox activities in plasmalemmaenriched vesicles isolated from boronand zinc-deficient chick pea roots. Journal of Plant Physiology, 146: 65257.

Lindsay, W. L. Inorganic equilibria affecting micronutrients in soils. In: J.J. Mortvedt, F.R. Cox, L.M. Shuman, R.M. Welch, eds. Micronutrients in Agriculture. Soil Science Society of America Book Series No. 4, 2nd ed. Madison, WI: Soil Science Society of America, 1991, pp. 89-112.

Lohnis, M. P. 1937. Plant development in the absence of boron. Overgedrukt uit Mededeelingen van de Landbouwhoogeschool, 41: 3-36.

Loomis, W. D. and Durst, R. W. 1992. Chemistry and biology of boron. BioFactors, 3: 229-39. 
Lovett, C. J. and Dugger, W. M. 1984. Boron. In The Biochemistry of the Essential Ultra Trace Elements, ed. E Frieden, pp. 389-421. New York: Plenum.

Marschner, H. 1995. Mineral nutrition of higher plants. London: Academic Press.

Marschner, H. 1997. Mineral nutrition of higher plants. Academic Press, 2nd. Edition, London, 889 p.

Morre, D. J., Navas, P., Penel, C. and Castillo, F. J. 1986. Auxin-stimulated NADH oxidase (semidehydroascorbate reductase) of soybean plasma membrane: role in acidification of cytoplasm? Protoplasma, 133: 195-97.

Mozafar, A. 1993. Role of boron in seed production. In Boron and its role in crop production, ed. U. C. Gupta, 186206. Boca Raton, FL: CRC Press.

Nyomera, A.M.s., Brown, P.H., Freeman, M., 1997. Fall foliar applied boron increase tissue boron concentration and nut set of almond. J. Am. Soc. Hortic. Sci., 122, 405-410.

Nyomora, A. M. S., Brown, P. H., Pinney, K. and Polito, V. S. 2000. Foliar application of boron to Almond trees affects pollen quality. Journal of American Society of Horticultural Science. 125: 265-270.

Obermeyer, G., Kriechbaumer, R., Strasser, D., Maschessnig, A. and Bentrup, F. W. 1996. Boric acid stimulates the plasma membrane HC-ATPase of ungerminated lily pollen grains. Physiology of Plants, 98: 281-90.

Parr, A. J. and Loughman, B. C. 1983. Boron in membrane functions in plants. In Metals and Micronutrients: Uptake and Utilization by Plants, ed. DA Robb, WS Pierpoint, pp. 87-107. Annual Proceedings of Phytochemistry Society of Europe. London: Academic.

Peryea, F. J. 1994. Boron nutrition in deciduous tree fruits. In: Peterson, A. B. and Stevens, R. G. (Eds.), Tree Fruit
Nutrition. Good Fruit Grower, Yakima, Washington, pp. 95-99.

Peryea, F.J., Neilsen, D., Neilson, G., 2003. Boron maintenance sprays for apple: early season application and tankmixing with calcium chloride. HortScience, 38, 542-546.

Pollard, A. S., Parr, A. J. and Loughman, B. C. 1977 . Boron in relation to membrane functions in higher plants. Journal of Experimental Botany, 28: 831-41.

Robbertse, P. J., Lock, J. J., Stoffberg, E. and Coetzer, L. A. 1990. Effect of boron on directionality of pollen tube growth in Petunia and Agapanthus. Aferican Journal of Botany, 56: 487-92.

Shear, C. B. and Faust, M. 1980 Nutritional ranges in deciduous tree fruits and nuts. Horticulture review. 2: 142-163.

Shkolnik, M. Y. 1984. Trace Elements in Plants. New York: Elsevier Schmucker T. 1935. Uber den Einfluss von Borsaure and Pflanzen, insbesondere keimende Pollekorner. Planta, 23: 26483.

Shorrocks, V. M. 1997. The occurrence and correction of boron deficiency.Plant and Soil. 193:121-148.

Tanada, T. 1983. Localization of boron in membranes. Journal of Plant Nutrition, 6: 743-49.

Thompson, M. 1996. Flowering, pollination and fruit set. p. 223-241. In: A.D. Webster and N.E. Looney (eds.), Cherries: crop physiology, production and uses, $\mathrm{CAB}$ International, Wallingford, UK.

Thompson, M. 1996. Flowering, pollination and fruit set. p. 223-242. In: A. D. Webster and N. E. Looney (eds.). Cherries: Crop physiology, production and uses. $\mathrm{CAB}$ International, Wallingford.

Thurzo, S., Szabo, Z., Nyeki, J., Silva, A. P., Nagy, P. T. and Goncalves, B. 2010. Effect of boron and calcium sprays on 
photosynthetic pigments, total phenols and flavonoid content of sweet cherry (Prunus avium 1.). Acta Horticulture. 868: 457-461.

Tsang, T. and Ghose, S. Nuclear magnetic resonance of $1 \mathrm{H}, 7 \mathrm{Li}, 11 \mathrm{~B}, 23 \mathrm{Na}, 27 \mathrm{Al}$ in tourmaline (elbaite). American Mineralogist, 58: 224-229, 1973.

Visser, T. 1955. Germination and storage of pollen. Meded. Landb. Hoogesch. 55: $1-68$.

Whetstone, R. R., Robinson, W. O. and Byers, H. G. Boron Distribution in Soils and Related Data. U.S. Dep. Agric. Tech. Bull. No. 797, Washington, DC, 1942.

Wilcox, J.C. and Woodbridge, C.G. 1942. Some effects of excess boron on the storage quality of apples. Scientific Agriculture, 23: 332-341.

Wojcik, P. and Wojcik, M. 2006. Effect of boron fertilization on sweet cherry tree yield and fruit quality. Journal of plant Nutrition, 29: 1755-1766.

Wojcik, P., Wojcik, M. and Klamkowski, K. 2008. Response of apple trees to boron fertilization under conditions of low spoil boron availability. Scientia Horticulturae, 116: 58-64.

Xuan, H., Streif, J., Saquet, A. A. and Bangerth, F. 2003. Boron Application Affects Respiration and Energy Status of 'Conference' Pears during CAStorage. Acta Horticulture, 628: 167174.

Yogaratnam, N. and Greenham, D. W. P. 1982. The applications of foliar sprays containing nitrogen, magnesium, zinc, and boron to apple trees. I. Effect on fruit set and cropping. Journal of Horticuture Science, 57: 151-158.

\section{How to cite this article:}

Gowhar A. Dar. 2017. Impact of Boron Nutrition in Fruit Crops. Int.J.Curr.Microbiol.App.Sci. 6(12): 4145-4155. doi: https://doi.org/10.20546/ijcmas.2017.612.476 